\title{
Relationship Between Knowledge and Attitudes of Pregnant Women with Participation in Pregnancy Exercise at Puskesmas Pariaman
}

\author{
Maidawilis $^{1 *}$, Sandra Dewi ${ }^{2}$, and Yesi Maifita ${ }^{3}$ \\ ${ }^{123}$ Universitas Negeri Padang \\ ${ }^{*}$ Corresponding author. Email: maidawilis73@gmail.com
}

\begin{abstract}
According to the WHO (World Health Organization), WHO estimated that every years more than 585 thousand mothers die during pregnancy or childbirth. Pregnancy exercised was one of the promotive and preventive effort to reduced IMR and AKI. Childbirth is a monumental time for a woman. The research objective was to determined the relationship between attitude and knowledge of pregnant women and participation in pregnancy exercise at the Pariaman Health Care in 2019.This researched was quantitative, while the type of researched used is cross sectional researched. This researched was conducted at Pariaman Public Health Center from June until July 2019. The population in this studied were pregnant women on the third trimester, the sample was taken as many as 42 people.The results of this research analysis show that more than half of respondent knowledges $(52.4 \%)$ is still low. More than half of the respondents' attitudes (54.8\%) are still negative. More than half of the respondents $(64.3 \%)$ did not participate in pregnancy exercise. There was a significant relationship between participation and knowledges in pregnancy exercise, with $\mathrm{p}$ value of $0.005<0.05$. There was a significant relationship among attitudes and participation in pregnancy exercise, with $\mathrm{p}$ value of $0.001<0.05$.It is hoped that health workers will play a more active role in providing counseling and increasing information about pregnancy exercise both to pregnant women who are at the polindes or other meeting places. Increased promotion can be by distributing leaflets or brochures containing information about the benefits of pregnancy exercise.
\end{abstract}

Keywords: Knowledge, Attitudes, Participation in Pregnant Gymnastics

\section{BACKGROUND}

Benchmarks for the success and ability of a country's health services are measured by maternal mortality and perinatal mortality rated. Maternal Mortality Rate (MMR) is the maternal in mortality rate which is a direct result of the reproductive process, while the infant mortality rate (IMR) is the infant mortality rate until the age of 1 year (Depkes RI, 2004).

Pregnance and childbirth to a mother is a natural processed. So this natural processed to run well and smooth, not to developed into a pathological stated and to obtain an optimally healthy mother and baby, efforts are needed from an early age, namely before the mother enters pregnancy. Preparations and efforts that should be made by the family starting the month before pregnancy occurs, for example carrying out a physical examination including the function of the reproductive organs and other specific examinations if necessary, treating existing diseases and improving and improving the mother's nutritional status. This is done so that the pregnancy takes place in excellent health conditions so that disease during pregnancy and childbirth can be prevented or reduced and the maternal mortality rate (MMR) can be minimized even more. (MOH, 2012).

According to WHO (World Health Organization) in 2018, estimates that worldwide each year more than 585 thousand mothers die during pregnancy or childbirth. (Ministry of Health, 2018).

In Indonesia, more than 300 out of every 100 thousand pregnancies end in death in pregnant women, and this is higher than in other countries, even six times higher than neighboring Malaysia. Meanwhile, the MMR in West Sumatra in 2017 was 228 from 100,000 live births. The Minister of Health has made various efforts to accelerate the reduction of MMR and IMR, including starting to launch various health programs in districts / cities that are focused on preventive and promotive activities in the Maternal and Child Health program (Dinkes West Sumatra, 2017).

Pregnancy exercise is either the promotive and preventive efforted to reduce IMR and AKI. Childbirth is a monumental time for a woman. Feelings of fear and anxiety in facing childbirth usually occur in pregnant women and cause physical and psychological tensions. The changes in the first pregnant woman are in the form 
of physical changes, namely in the form of an enlarged abdomen which causes aching sensation in the waist, varicose veins, cramps in the legs, and the second change is a psychological change, namely in the form of tension that causes anxiety. The benefits of doing pregnancy exercise are many, including maintaining physical fitness, relaxing the muscles of the body, especially the muscles related to the labor organs, besides that of course it will strengthen mentally in dealing with childbirth. (Adiyono, 2012).

Pregnancy exercise is one of the activities in services during pregnancy (prenatal care). Pregnancy exercise will provide a better outcome of pregnancy products (outcome) than for pregnant women who do not do pregnancy exercise. Pregnancy exercise serves to relax tensions, reduce aches, shrink the perineum and can breathe regularly in the face of childbirth, psychologically also has a positive impact to reduce panic and ultimately the labor process can run smoothly (Sari \& Monica, 2014)

Pregnancy exercise has also been shown to help change the body's metabolism during pregnancy, the advantages of which are high oxygen consumption for the body, cardiac blood flow, stroke volume and cardiac output. In addition, it can result in changes in the role of the heart during pregnancy which is useful for helping heart function so that pregnant women will feel healthier and not feel short of breath and make the body fresh and fit. In pregnant women who do regular pregnancy exercises, it is reported that their labor (Kala II) is shorter and reduces the occurrence of fetal distress at the time of delivery.

Pregnancy exercise is something new among the Indonesian population. Maybe for people in big cities like Jakarta, Bandung, Surabaya and so on, this pregnancy exercise is not a strange thing, but it does not mean that everyone understands and realizes that pregnancy exercise is useful for pregnant women. Pregnant exercise that is given in hospitals and in health centers on a regular basis and is guided along with the method of pregnancy exercise is an assistance that cannot be ignored, as is pregnancy hygiene. From the description above, it is clear that pregnancy exercise is very beneficial for pregnant women. However, the many benefits obtained by participating in pregnancy exercise do not make pregnant women have awareness in implementing it, this can be seen from the low visits of pregnant women to the pregnancy exercise activities held (LocanaRoosytasari, 2009).

According to Green, factors that influence behavior are determined by 3 types, predisposing factors (beliefs and values, knowledge, and attitudes), enabling factors (facilities or infrastructure that support or facilitate the occurrence of a person's behavior) and reinforcing factors derived from family, peers, teachers and health workers (Notoatmodjo, 2014). Meanwhile, according to (LocanaRoosytasari, 2009) family support, knowledge, the role of officers, attitudes and factors in health service affordability affect the activeness of mothers in participating in pregnancy exercise.

Based on data by the Pariaman City Public Health Office, in 2018 the number of women who are pregnant were recorded at 1,680 people. For more details, see table 1.1 below

Table 1. Number of Pregnant Women in Kota Pariaman

\begin{tabular}{|l|l|l|}
\hline No & Puskesmas & $\begin{array}{l}\text { Jumlah } \\
\text { Ibu } \\
\text { Hamil }\end{array}$ \\
\hline 1 & Air Santok & 160 \\
\hline 2 & Sikapak & 193 \\
\hline 3 & Padusunan & 168 \\
\hline 4 & Kurai Taji & 242 \\
\hline 5 & Marunggi & 112 \\
\hline 6 & Pariaman & 616 \\
\hline 7 & Naras & 189 \\
\hline \multicolumn{2}{|l|}{ Total } & 1.680 \\
\hline
\end{tabular}

Source: Kota Pariaman Health Office, 2019

Meanwhile, the highest the number of women who are pregnant was found in the work area of the Pariaman Puskesmas, namely 616 people, while the third semester of pregnancy was 138 people. While the preliminary data that the researchers got from the Pariaman Health Center, it is known that one of the programs implemented in order to improve the health of pregnant women is by holding pregnancy exercise activities. This activity has been carried out since 2011 . However, in its implementation, the participation of pregnant women in joining this program is still low, where visits from mothers only reach $+15 \%$ of the total pregnant women. Meanwhile, during pregnancy exercise, the facilities provided for pregnant women are exercise instructors for pregnant women, comfortable rooms and also a snack menu for pregnant women.

Research by Randu (2016) in the work area of the Junrejo Health Care, Batu City, shows that the participation of pregnancy exercise in pregnant women is related to knowledge, husband's support and the role of officers. Meanwhile, research conducted by Renty (2015) found that the attitudes and support of officers were related to the participation of mothers in pregnancy exercise.

The results of the author's initial interviews on April 26, 2019 with 15 pregnant women who came to visit the Pariaman Health Center, it was found that 8 of them did not know well the implementation of pregnancy exercise and the benefits of pregnancy 
exercise, while 7 pregnant women understood pregnancy exercise and the benefits it got. by doing pregnancy exercises. In addition, 7 pregnant women expressed their attitude that gymnastics movements could endanger their womb. Of the 15 pregnant women, only 4 said they participated in the pregnancy exercise held at the puskesmas. Meanwhile, the results of the interview with the researcher showed that the interest of pregnant women in participating in pregnancy exercise was still low, because from the activities held, the average pregnant woman who came for pregnancy exercise was only about 20 people.

From the description, the authors were interested in conducting researched with the title "Relationship between Knowledge and Attitudes of Pregnant Women with Participation in Pregnancy Exercise at Puskesmas Pariaman in 2019"

\section{RESEARCH METHODS \\ Research Type and Design}

This type of researched was descriptive analytic with a cross sectional studied, namely the strategy used to obtain clearer information about facts as well. identifies as a whole an event being researched, where the independent variable and the dependent variable are collected as a measuring tool and at the same time (Notoatmodjo, 2014).

\section{Research Location and Time}

This research was conducted at the Pariaman Health Center, the research was conducted on the fourth week of June and the first week of July 2019

\section{Research Population and Samples}

The populations in that studied were all third trimester of pregnant women recorded until May 2019, amounting to 138 people. The sampling technique apply in the study was accidental sampling, which is taking samples that were obtained by chance at the time of the study so that the total sample size was 42 people.

\section{RESULTS AND DISCUSSION \\ Univariate Analysis \\ Respondent's knowledge}

Table 2. Distribution Frequency of Respondent Based on Knowledge in Pariaman Health Center work area on 2019

\begin{tabular}{lll}
\hline Pengetahuan & Frekuensi & \% \\
\hline Rendah & 22 & 52.4 \\
Tinggi & 20 & 47.6 \\
\hline Jumlah & $\mathbf{4 2}$ & $\mathbf{1 0 0}$ \\
\hline
\end{tabular}

Based on the table 5.1, it can be see that more than half $(52.4 \%)$ of respondent has low knowledge

\section{Attitude of Respondents}

Table 3. Respondent Frequency Distribution Based on attitudes in Pariaman Health Center work area on 2019

\begin{tabular}{|l|l|l|}
\hline Sikap & Frekuensi & \% \\
\hline Negatif & 23 & 54.8 \\
\hline Positif & 19 & 45.2 \\
\hline Jumlah & $\mathbf{4 2}$ & $\mathbf{1 0 0}$ \\
\hline
\end{tabular}

Based on the table 5.2, we can see that more than half $(54.8 \%)$ of respondents have a negative attitude

\section{Pregnant exercise participation}

Table 4. Frequency Distribution of Respondents Based on Pregnant Exercise Participation in the Pariaman Health Center working area in 2019

\begin{tabular}{|l|l|l|}
\hline KeikutsertaanSenamhamil & Frekuensi & \% \\
\hline Tidakteratur & 27 & 64.3 \\
\hline Teratur & 15 & 35.7 \\
\hline Jumlah & $\mathbf{4 2}$ & $\mathbf{1 0 0}$ \\
\hline
\end{tabular}

Based on table 5.3, it is known that more than half $(64.3 \%)$ of respondents do not regularly participate in pregnancy exercise

\section{Bivariate Analysis Knowledge Relationship with Pregnant exercise participation}

Table 5. The relationship among knowledge and pregnancy exercise participation in the work area of Puskesmas Pariaman

2019 year

\begin{tabular}{|c|c|c|c|c|c|c|c|}
\hline \multirow[t]{3}{*}{$\begin{array}{l}\text { Penge- } \\
\text { tahuan }\end{array}$} & \multicolumn{4}{|c|}{$\begin{array}{l}\text { Keikutsertaan senam } \\
\text { hamil }\end{array}$} & \multirow{2}{*}{\multicolumn{2}{|c|}{ Total }} & \multirow{2}{*}{$\begin{array}{l}\text { P- } \\
\text { Value }\end{array}$} \\
\hline & \multicolumn{2}{|c|}{$\begin{array}{l}\text { Tidakteratu } \\
\mathbf{r}\end{array}$} & \multicolumn{2}{|c|}{ Teratur } & & & \\
\hline & f & $\%$ & $\mathbf{f}$ & $\%$ & $\mathbf{N}$ & $\%$ & \multirow{4}{*}{0,005} \\
\hline Rendah & 19 & 86,4 & 3 & 13,6 & 22 & 100 & \\
\hline Tinggi & 8 & 40 & 12 & 60 & 20 & 100 & \\
\hline Jumlah & 27 & 64,3 & 15 & 35,7 & 42 & 100 & \\
\hline
\end{tabular}

Based on table 5.4, we can see that of the 22 respondents with low knowledges, 19 (86.4\%) did not participate in pregnancy exercise, 3 people $(13.6 \%)$ participated in pregnancy exercise. Meanwhile, of the 20 respondents who had high knowledge, $8(40 \%)$ did not participate in pregnancy exercises and $12(60 \%)$ participated in pregnancy exercises.

The results of the significance test on the relationship between knowledge and participation in pregnant exercise showed $\mathrm{p}$ value $=0.005<\alpha \quad 0.05$, 
which means that there is a significant relationship between knowledge and participation in pregnancy exercise.

Relationship between attitudes and pregnancy exercise participation

Table 6. The relationship between attitude and pregnancy exercise participation in the Pariaman Health Center work area in 2019

\begin{tabular}{|c|c|c|c|c|c|c|c|}
\hline \multirow[t]{3}{*}{ Sikap } & \multicolumn{4}{|c|}{$\begin{array}{l}\text { Keikutsertaansenamhami } \\
\text { l }\end{array}$} & \multirow{2}{*}{\multicolumn{2}{|c|}{ Total }} & \multirow{2}{*}{$\begin{array}{l}\mathbf{P} \\
\text { Value }\end{array}$} \\
\hline & \multicolumn{2}{|c|}{$\begin{array}{l}\text { Tidakdilak } \\
\text { ukan }\end{array}$} & \multicolumn{2}{|c|}{ Dilakukan } & & & \\
\hline & f & $\%$ & f & $\%$ & $\mathbf{N}$ & $\%$ & \multirow{4}{*}{0,002} \\
\hline Negatif & 20 & 87 & 3 & 13 & 23 & 100 & \\
\hline Positif & 7 & 36,8 & 12 & 63,2 & 19 & 100 & \\
\hline Jumlah & 27 & 64,3 & 15 & 35,7 & 42 & 100 & \\
\hline
\end{tabular}

Based on table 5.5, we can see that of the 23 respondents who have a negative attitudes, $20(87 \%)$ did not participate in pregnancy exercise, 3 people $(13 \%)$ participated in pregnancy exercise. Meanwhile, of the 19 respondents who have a positive attitudes, 7 (36.8\%) did not participate in pregnancy exercises and 12 $(63.2 \%)$ participated in pregnancy exercises. The results of the significance test on the relationship between attitudes and participation in pregnant exercise showed $\mathrm{p}$ value $=0.002<\alpha 0.05$, which means that there is a significant relationship between attitudes and participation in pregnant exercise.

\section{Discussion}

\section{Univariate Analysis}

\section{Respondent's knowledge}

The results of the analysis regarding the level of knowledge of respondents regarding pregnancy exercise, it was found that more than half of the respondents, namely 22 people $(52.4 \%)$ had low knowledge and 20 people (47.6\%) had high knowledge.

Research conducted by Artika (2016), about the factor that influence pregnant womens with the participation of pregnant exercise in the Sic Cincin Health Center Work Area in 2016, it was also found that more than some pregnant women had low knowledge, namely $68.9 \%$.

According to Notoatmodjo (2010) knowledge is the result of tofu and this occurs after people sense a certain object. Sensing occurs through the five human senses, namely the senses of sight, hearing, smell, taste and touch. Some human knowledge is obtained through the eyes and ears. One of the factors affecting knowledge is the level of education.

Based on the results of the study, it is show that more than half of the respondents still have a poor understanding of pregnancy exercise. Respondents still think that pregnancy exercise is a healthy exercise and they do not understand further that pregnancy exercise is a movement therapy to facilitate childbirth. In addition, many respondents also did not understand when and how often pregnant women should do exercise

According to the author's assumption, the total of respondents who have low knowledge is due to the lack of activity of respondents in seeking information about pregnancy exercise, such as lack of interaction with health workers. In addition, many respondents also have low education factors, so it is difficult for them to analyze existing information into new knowledge or insights.

\section{Attitudes of respondents}

The results of the analysis of the respondents' attitudes regarding pregnancy exercise, it was found that more than half of the respondents, 23 people $(54.8 \%)$ had negative attitudes and 19 people $(45.2 \%)$ had positive attitudes. Research conducted by Abdi Sabili (2014), it was also found that more than some respondents had negative attitudes about pregnancy exercise, which was $63.4 \%$.

Attitude was a reaction or respond that is still closed from someone to a stumulus or object. The manifestation of attitude cannot be seen, but can only be interpreted in advance of closed behavior. According to Newcomb in Notoatmodjo, this manner was a readiness or willingness to act and not an implementation of particular motives (Notoatmodjo, 2010).

Based on the analysis of the answers given. Respondents' statements that describe a negative attitude appear to be mostly found by respondents who think that pregnancy exercise is not good for their condition who is pregnant, besides that they also state that many other pregnant women also don't follow it.

More negative attitudes are found than positive attitudes. This situation certainly shows the respondent's readiness to actively participate in pregnancy exercise is still lacking. According to the researcher's analysis, there are still many respondents who have negative attitudes due to the low of the respondent knowledges who are still low, so that their low understanding of pregnancy exercise causes a lot of negative responses.

\section{Participation in pregnancy exercise}

The results of the study on the participation of pregnant exercise found that 27 respondents (64.3) were not regularly doing pregnancy exercise and 19 people $(45.2 \%)$ were good at carrying out pregnancy exercise.

Research conducted by YurbainaSusila (2017), it was also found that more than some respondents $(62.4 \%)$ were not active in participating in pregnancy exercise. 
The type of exercise that is most suitable for pregnant women is pregnancy exercise. Pregnancy exercise movements are in accordance with the many physical changes such as the genital organs, a bigger stomach, etc. By doing pregnancy exercise regularly and intensively, pregnant women can maintain the optimal health of the body and the fetus.

Based on the results, it turns out that many respondents interest in doing pregnancy exercises is still low. Even though pregnant exercise is very useful for improved the health of pregnancy women, the many benefits obtained by doing pregnancy exercise are not accompanied by the high interest of the respondents to participate in pregnancy exercise which is held regularly at the health center.

\section{Bivariate analysis}

\section{The relationship between knowledge and} pregnancy exercise participation

Based on results of the bivariate analysis, it show that out of 22 respondents with low knowledge, 19 $(86.4 \%)$ did not participate in pregnancy exercise, 3 (13.6\%) participated in pregnancy exercise. Meanwhile, of the 20 respondents who had high knowledge, 8 (40\%) did not participate in pregnancy exercises and $12(60 \%)$ participated in pregnancy exercises.

The results of the significance test on the relationship between knowledge and participation in pregnant exercise showed $\mathrm{p}$ value $=0.005<\alpha 0.05$, which means that there is a significant relationship between knowledge and participation in pregnancy exercise.

In line with research conducted by YurbainaSusila (2017), it was also found that there was a link or relationship between knowledge and participation in pregnancy exercise where the $\mathrm{p}$ value was $0.002<0.05$.

Notoatmodjo (2010) states that knowledge is a very important domain for the forming of someone actions. If the respondent's knowledge is low, it will be difficult for someone to apply it in real practice because knowledge is a very important domain for the forming of someone behavior. Respondents will regularly visit health services to participate in pregnancy exercise if they have high knowledge. Knowledge is very important for the formation of one's actions, behavior that is based on knowledge will be more lasting than behavior that is not based on knowledge.

The lack of understanding that is owned by respondents about pregnancy exercise causes respondents to not have a high interest in actively doing pregnancy exercises. This is because respondents do not know well what benefits can be obtained from participating in pregnancy exercise.
According to the authors' assumptions, the information factor is not balanced, such as information stating that pregnancy exercise movements can pose a risk to the health of the mother and fetus and also the misconception from the public that pregnant women should not make many movements and have to get lots of rest.

\section{The relationship between attitude and participation in pregnancy exercise}

The results of research on the relationship among attitudes and participation in pregnancy exercise, it is known that of the 23 respondents who were negative, 20 $(87 \%)$ did not participate in pregnancy exercise, 3 (13\%) participated in pregnancy exercise. Meanwhile, of the 19 respondents who have a positive attitude, 7 $(36.8 \%)$ didn't participate in pregnancy exercises and 12 $(63.2 \%)$ participated in pregnancy exercises.

The results of the significance test on the relationship between attitudes and participation in pregnant exercise showed the results of the $p$ value $=$ $0.002<\alpha 0.05$, which means that there are a significant relationships among attitudes and participation in pregnancy exercise.

Research conducted by Artika (2016), regarding the factors that influence pregnant women with the participation of pregnancy exercise in the Sic Cincin Health Center Work Area in 2016, also found a relationship with a $\mathrm{p}$ value of 0.002 .

Attitude is a description of whether someone likes or dislikes an object. Attitude was also response from a person to a encouragement which is also a readiness to act. In this case, the respondent's readiness to visit the polindes seems to be still lacking (Notoatmodjo, 2010).

There are still many respondents who think that pregnancy exercise can be dangerous for their wombs, so that their interest in participating in pregnancy exercise is low. As a result of this wrong response, the respondent was afraid and did not want to do pregnancy exercises. In addition, they are also less motivated by the surrounding environment, like many other pregnant women who do not participate in pregnancy exercises, making them slothful to go to health services to do pregnancy exercises.

\section{CONCLUSIONS AND RECOMMENDATIONS}

Conclusion

From the results of the research on the Relationship among Knowledge and Attitudes of Pregnant Women with Pregnant Exercise Participation at Pariaman Public Health Center in 2019, it can be concluded that: 
1. More than half of the respondent knowledge (52.4\%) is still low

2. More than half of the respondents' attitudes $(54.8 \%)$ are still negative

3. More than half of the respondents $(64.3 \%)$ did not participate in pregnancy exercise

4. There is a significant relationship between knowledge and participation in pregnancy exercise, with a $\mathrm{p}$ value of $0.005<0.05$.

5. There is a significant relationship between attitudes and participation in pregnancy exercise, with a $\mathrm{p}$ value of $0.001<0.05$

\section{Suggestion}

Health workers should play a more active role in providing counseling and increasing information about pregnancy exercise both to pregnant women who are at the polindes or other meeting places. Increased promotion can be by distributing leaflets or brochures containing information about the benefits of pregnancy exercise.

\section{REFERENCES}

[1] DEPKES. (2018). Hasil Utama Riset Kesehatan Dasar Tahun 2018. Kementrian Kesehatan Republik Indonesia.
[2] Depkes RI. (2004). Petunjuk Teknis Standar Pelayanan Minimal (SPM) Penyelenggaraan Perbaikan Gizi Masyarakat.

[3] Depkes RI. (2012). Penuhi Kebutuhan Gizi Pada 1000 Hari Pertama Kehiidupan. Www.Depkes.Go.Id.

[4] Dinkes Sumbar. (2017). Profil Dinas Kesehatan Sumatera Barat Tahun 2017. 1.https://doi.org/10.1017/S0021853700035192

[5] Memperoleh, G., Sarjana, G., \& Surakarta, U. M. (2009). Hubungan Antara Senam Hamil Dengan Proses Persalinan Normal Di Rumah Bersalin As Syifa ' Ul Ummah Grobogan.

[6] Notoatmodjo. (2014). Konsep Pengetahuan, dan Sikap.

Cell.https://doi.org/10.1016/j.cell.2009.01.043

[7] Notoatmodjo, S. (2010). Promosi Kesehatan, Teori \& Aplikasi, ed. revisi 2010. In Jakarta: Rineka Cipta. $\quad$ https://doi.org/10.1108/JMTM-03-20180075

[8] Sari, E. P., \& Monica, L. P. (2014). Relationship Between Pregnancy Exercise With Pain Contraction In Labour. Jurnal Ners Dan Kebidanan (Journal of Ners and Midwifery). https://doi.org/10.26699/jnk.v1i2.art.p104-107 